\title{
Exploring perceptions of the Mexican sugar-sweetened beverage tax among adolescents in north-west Mexico: a qualitative study
}

\author{
Ana G Ortega-Avila*, Angeliki Papadaki and Russell Jago \\ Centre for Exercise, Nutrition and Health Sciences, School for Policy Studies, University of Bristol, 8 Priory Road, \\ Bristol BS8 1TZ, UK
}

Submitted 20 April 2017: Final revision received 12 July 2017: Accepted 17 August 2017: First published online 24 0ctober 2017

\begin{abstract}
Objective: To explore awareness and perceptions of the sugar-sweetened beverage (SSB) tax implemented in Mexico in 2014 among a sample of Mexican adolescents, and to investigate how the tax has affected their purchases and intake of SSB.

Design: Qualitative.

Setting: Semi-structured interviews were conducted in April-May 2016. The data were analysed using thematic analysis.

Subjects: Adolescents residing in north-west Mexico ( $n$ 29, 55.2\% females), aged 15-19 years.

Results: Four main themes emerged: awareness of taxation; perceptions of how the tax has affected SSB intake; reasons why the tax was not perceived to have affected SSB intake; and preferences for substitution of the taxed SSB. Participants were mostly unaware of the tax and perceived that it would not cause reductions in their intake of SSB; they felt that the price increase was low and insufficient to affect intake. Taste preferences and 'addiction' to SSB were highlighted as the main reasons why participants perceived taxation would not affect intake. If SSB prices were to increase further via a higher tax, participants would consider substituting SSB with other beverages, namely home-made drinks (e.g. 100\% fruit juices), non-caloric, instant-flavoured drinks and water.

Conclusions: These findings provide important insights into the views of this sample of Mexican adolescents regarding the taxation of SSB, by pointing out several possible limitations of the tax policy in Mexico. These results could inform the design of future interventions directed at Mexican youth that would complement and strengthen the current SSB taxation.
\end{abstract}

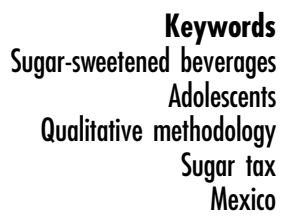

Obesity is a major public health problem in Mexico, with $70 \%$ of adults overweight or obese ${ }^{(1)}$. Data from the Mexican National Health and Nutrition Survey (Encuesta Nacional de Salud y Nutrición, ENSANUT 2012) indicate that $35 \cdot 8 \%$ of adolescents (12-19 years) in Mexico are either obese or overweight ${ }^{(1)}$. It is therefore important to examine the dietary practices of Mexican adolescents and how they could be altered to prevent weight gain.

Although obesity is a multifactorial problem, evidence suggests that sugar-sweetened beverage (SSB) intake is a significant driver of the obesity epidemic in children and adolescents $^{(2)}$. In a 7-year period (1999-2006), the daily energy intake from SSB among Mexican adolescents doubled from 418 to $941 \mathrm{~kJ}$ (100 to $225 \mathrm{kcal} ; P<0 \cdot 001)^{(3)}$. Moreover, SSB intake in Mexico is among the highest worldwide, with 163 litres consumed per capita per year $^{(4)}$. Reduction of SSB intake in the Mexican population has therefore become a public health priority. In 2013 the Mexican Congress approved a specific excise tax on any non-alcoholic beverages with added sugars, defined as a fixed dollar amount dependent on the quantity purchased. The tax took effect on 1 January 2014 and consisted of an increase of 1 peso (\$US 0.05, £0.04) per litre, which represents an approximate $10 \%$ price increase. A recent study showed that two years after the tax was implemented the average number of SSB purchases declined by $7 \cdot 6 \%^{(5)}$ and per capita SSB sales declined by $7 \cdot 3 \%{ }^{(6)}$. These findings suggest a potentially beneficial effect of the taxation. However, a number of gaps in the literature have been identified that warrant further investigation. First, the effect of the tax could be lower among high consumers of $\mathrm{SSB}^{(7)}$ and higher among groups with low socio-economic profiles ${ }^{(5)}$. Second, a $10 \%$ increase in price might not be sufficient to promote reductions in SSB intake; therefore, 
there might be a need for a higher tax to reduce the prevalence of obesity ${ }^{(8-11)}$. Third, if a higher tax were implemented, it is unclear what the SSB substitution patterns might be or whether people might shift to non-caloric beverages, cheaper SSB or other unhealthy foods ${ }^{(12)}$. Furthermore, in settings with informal markets (such as Mexico) prices may vary depending on beverage brands or purchase locations (e.g. street vendors, convenience stores or supermarkets) and a $10 \%$ increase in SSB prices might not be uniform, thereby potentially affecting the impact of the $\operatorname{tax}^{(4)}$. Finally, the success of the tax might depend on how informed and aware consumers are about it ${ }^{(13)}$.

To date, the effectiveness of the SSB tax in Mexico has been evaluated from an economic perspective, by assessing changes in SSB purchases and sales ${ }^{(5,6)}$. To our knowledge, no study has examined the perceptions of consumers regarding implementation of the tax and its potential to reduce SSB intake. Therefore, the current study aimed to qualitatively explore: (i) the awareness and perceptions of the current SSB tax among a sample of adolescents residing in north-west Mexico, an area that is likely to have a high intake of SSB; and (ii) their experiences of how taxation has affected their purchases and intake of SSB.

\section{Methods}

\section{Research design and participants}

Semi-structured interviews were conducted in the city of Hermosillo, Mexico, between April and May 2016. Participants were approached and recruited through their participation in an earlier cross-sectional online survey (August-September 2015) assessing the intake of SSB and its individual, social and environmental determinants among Mexican adolescents residing in this region (AG OrtegaAvila, A Papadaki and R Jago, unpublished results). This online survey was completed by 508 adolescents, aged 15-19 years, attending the last two years of high school and/ or the first year of university in Hermosillo (794342 inhabitants), the capital city of the state of Sonora, in north-west Mexico, where the intake of SSB is likely to be high. At the end of the survey, participants were asked to indicate their willingness to be contacted to participate in an interview. A total of $391(76.9 \%)$ adolescents expressed their interest by providing an email address and were sent an information sheet. Participants were purposively recruited into the current study to achieve a sample comprising both males and females and consumers of at least one portion of SSB daily, as previously assessed by the online survey (AG Ortega-Avila, A Papadaki and R Jago, unpublished results). Participants provided written informed consent prior to the interview and received 100 Mexican pesos (approximately \$US $5, £ 4$ ) at the end of the interview, as compensation for their time. The study was approved by the University of Bristol, School for Policy Studies Ethics Committee (SPS REC 14-15.A16).

\section{Data collection}

A total of thirty-seven adolescents ( $9.5 \%$ response rate) replied to the invitation email, showing an interest in participating in the interviews. Eight adolescents cancelled or did not show up on the day of the interview. Therefore, twenty-nine interviews were conducted in public spaces (cafés and university libraries) and participants' homes (if adolescents were under 18 years old), lasting an average of $35 \mathrm{~min}$ (27-50 min). Interviews were conducted by the same researcher, who was experienced and trained in conducting interviews, using a semistructured interview guide (see online supplementary material, Supplemental Table 1). The guide was developed with the objective of exploring factors associated with SSB intake and perceptions of the current SSB taxation (the present paper reports on adolescents' awareness and perceptions of the latter). For the purpose of the study, SSB were defined as carbonated and non-carbonated drinks that contain added sugars ${ }^{(14,15)}$ including soft drinks (carbonated drinks), fruit juices (excluding 100\% fruit juices), fruit-flavoured drinks, sport drinks, energy drinks, sweetened beverages (e.g. coffee/ tea) and flavoured milk ${ }^{(14-18)}$. Sweetened flavoured waters or aguas frescas, which are traditional Mexican beverages prepared with water, fresh fruit, cereals, flowers or seeds and added sugar ${ }^{(19)}$, were also included in the definition. The interview guide was piloted with two adolescents within the participants' age range who did not participate in the study. Feedback from this pilot clarified the questions, wording and formality of the interview. During the interviews, the sequence and wording of the questions were modified to explore emerging themes. At the end of each interview, the researcher summarised the discussion points to confirm the accuracy of the themes raised with participants.

The interviews were recorded, transcribed verbatim and anonymised. All transcripts were checked against the recordings to verify accuracy and credibility and small changes were made where necessary. Data collection and analysis proceeded in parallel, but considering the exploratory nature of our study, the number of interviews with this homogeneous sample of adolescents was sufficient to capture perceptions of SSB taxation and to reach code saturation during analysis ${ }^{(20)}$.

\section{Data analysis}

Data analysis was carried out in Spanish and translation of the data into English was limited to selected quotes ${ }^{(21)}$. Conducting the analysis in the original language is recommended to prevent misinterpretations of participants' statements ${ }^{(21-23)}$. Themes and quotes were translated into English by the researcher who conducted the interviews, who is a native Spanish speaker, and backtranslated to Spanish by an independent bilingual researcher $^{(22,24)}$. Relevant quotes are presented in English and Spanish ${ }^{(25)}$. 
Thematic analysis of the interview transcripts, using the framework approach, was used to analyse the data. This method was selected because it provides a systematic guide of data analysis that seeks to draw descriptive and exploratory conclusions clustered around themes, but at the same time retains links to the data ${ }^{(26,27)}$. As suggested by Gale et al., the framework analysis was conducted in five stages. First, familiarisation with the data was carried out by reading transcripts repeatedly. Second, two trained researchers (both Mexicans, Spanish speakers) independently coded three interview transcripts to validate the coding process and to begin classifying data, so they could be compared systematically with the rest of the data set ${ }^{(27)}$. Third, a number of meetings were held to discuss the coded sections and any coding discrepancies (e.g. differences in terminology used by the coders and whether codes were useful to answer the research questions). Both coders agreed on a set of codes that formed an initial framework. Based on this, three more interview transcripts were independently coded, taking account of any new themes, codes and nuances. The two coders met again to refine the initial framework, identify new themes and incorporate new codes. Inter-coder reliability was $95 \%$, as assessed by dividing the number of agreements by the sum of agreement and disagreements. The final framework consisted of eleven codes clustered into four themes (see online supplementary material online, Supplemental Table 2). Fourth, indexing (systematically applying the framework to all transcripts) was carried out by one researcher using the qualitative data analysis software NVivo version 10 (QRS International Pty Ltd, UK). Finally, charting took place by rearranging the data in a chart. Emerging themes and codes are illustrated by representative quotations from participants (indicated as participant number (e.g. P1)/male (M) or female (F)/age in years). These were selected to best reflect the diversity of responses.

\section{Results}

Interviews were conducted with twenty-nine adolescents (sixteen females and thirteen males, ranging in age between 15 and 19 years; mean 17.0 (SD 1.4) years). Participant characteristics and mean SSB intakes are shown in Table 1. There were no differences between males and females in age, socio-economic status or anthropometric characteristics, but male participants consumed a higher amount of SSB than females (1159.1 v. 908.5 ml/d, $P=0.60)$. There were no differences in age $(17 \cdot 0 \quad v .16 .9$ years, $P=0 \cdot 14)$, BMI $\left(22.3 v .22 .4 \mathrm{~kg} / \mathrm{m}^{2}, P=0.77\right)$ and intake of SSB (1020.8v. $933.2 \mathrm{ml} / \mathrm{d}, P=0.68)$ between participants who took part in the interviews ( $n$ 29) and those who did not $(n$ 479). Four main themes were identified that should be considered for the design of future interventions directed at this sample of Mexican youth, to complement the SSB taxation.

\section{Awareness of taxation}

Participants were mostly unaware of the SSB taxation:

'I didn't know why the price went up.' / 'No sabía porque habían subido de precio.' (P4/F/17)

and some reported not having noticed a price increase:

'I didn't know anything ... honestly I haven't noticed.' / 'No sabía nada ... la verdad no me he dado cuenta.' (P2/F/15)

If participants were not aware of the taxation, the interviewer briefly explained the tax policy. Two participants then realised that they had heard about the price increases. In total, five participants stated that they were aware of the taxation of SSB in Mexico, mostly via mass media, such as television and the news:

'I have only heard about this on the news, that the prices increased due to health issues, but apart from

Table 1 Sociodemographic characteristics and sugar-sweetened beverage intake of the study participants: adolescents aged 15-19 years residing in north-west Mexico, April-May 2016

\begin{tabular}{|c|c|c|c|c|c|c|}
\hline & \multicolumn{2}{|c|}{ Total $(n 29)$} & \multicolumn{2}{|c|}{ Females ( $n$ 16) } & \multicolumn{2}{|c|}{ Males (n 13) } \\
\hline & Mean & SD & Mean & SD & Mean & SD \\
\hline Age (years) & $17 \cdot 0$ & 1.4 & $16 \cdot 8$ & 1.5 & $17 \cdot 3$ & 1.2 \\
\hline Weight (kg) & 63.3 & $13 \cdot 0$ & 63.4 & $12 \cdot 0$ & $63 \cdot 2$ & $14 \cdot 6$ \\
\hline Height (m) & 1.68 & 0.10 & 1.65 & 0.07 & 1.72 & 0.77 \\
\hline BMI $\left(\mathrm{kg} / \mathrm{m}^{2}\right)$ & $22 \cdot 3$ & 4.4 & $23 \cdot 1$ & 3.7 & $21 \cdot 3$ & $5 \cdot 0$ \\
\hline SES $(0-10)^{*}$ & $5 \cdot 6$ & 2.5 & $5 \cdot 2$ & $3 \cdot 2$ & $6 \cdot 2$ & 1.7 \\
\hline \multicolumn{7}{|l|}{ Mean daily intake of SSB $(\mathrm{ml} / \mathrm{d}) \dagger$} \\
\hline Sweetened juices/fruit drinks & $368 \cdot 3$ & $442 \cdot 7$ & $290 \cdot 2$ & $298 \cdot 2$ & 447.8 & 554.7 \\
\hline Regular soft drinks & 189.3 & $169 \cdot 2$ & $230 \cdot 0$ & 178.6 & $186 \cdot 6$ & $175 \cdot 5$ \\
\hline Aguas frescas & 325.7 & $419 \cdot 6$ & $306 \cdot 4$ & $406 \cdot 1$ & $306 \cdot 0$ & $414 \cdot 0$ \\
\hline Sweetened iced teas & 259.5 & $376 \cdot 6$ & $265 \cdot 7$ & $300 \cdot 0$ & $301 \cdot 2$ & $506 \cdot 4$ \\
\hline Coffee and/or tea, with sugar & $242 \cdot 4$ & 277.9 & 223.8 & $154 \cdot 1$ & $142 \cdot 9$ & 378.1 \\
\hline Sport and energy drinks & $256 \cdot 6$ & $419 \cdot 6$ & $169 \cdot 2$ & 50.5 & $299 \cdot 1$ & 535.3 \\
\hline Total SSB & $1020 \cdot 8$ & 1297.6 & 908.5 & $722 \cdot 8$ & $1159 \cdot 9$ & $1718 \cdot 0$ \\
\hline
\end{tabular}

SES, socio-economic status; SSB, sugar-sweetened beverages.

*SES was assessed based on an asset index comprising availability of basic and non-basic goods and durables and educational attainment of the household head.

†Intake of SSB was assessed via a sixteen-item beverage intake questionnaire (AG Ortega-Avila, A Papadaki and R Jago, unpublished results). 
that I haven't heard more.' / 'Nomás lo había escuchado ahí por noticias, que se aumentó por cuestiones de salud, pero de ahí en fuera no escuche mas.' (P23/M/16)

Among participants who knew about the tax, a few were aware of its aim to some extent, as two participants stated:

'Oh yes I heard, something like let's charge them more so that they [people] don't buy [SSB] because we are very fat.' / 'iAh no si escuche!, algo así de que vamos a cobrarles más para que no las compren [bebidas azucaradas] porque estamos muy gordos.' (P21/M/18)

'Yes, something about [SSB] are more expensive now. It is because children in Mexico are fat.' / 'Si, algo de que esta más caro. Es por los niños gordos en México.' (P16/F/16)

Similarly, some participants explained that they knew something about the taxation; however, they acknowledged that they did not know the details, such as the amount of the price increase or when the tax was implemented:

'I don't know if the tax has already been implemented, but I knew that the Mexican government wanted to impose taxes on sugar, juice, sodas, tea, and I had heard that water too, they also wanted to add taxes to water.' / 'No sé si ya entro en vigor lo de los impuestos, pero yo sabia que el gobierno mexicano quería ponerle impuesto a las bebidas con azúcar, jugos, sodas, te, y había escuchado por ahí que el agua también, que también le quieren agregar impuestos.' (P24/M/17)

'... I don't really know much, I couldn't tell you "this is the tax".' / '... pero en realidad no conozco tanto, no te podría decir "esto es el impuesto".' (P12/F/18)

A few participants were aware of the increased price of SSB; however, they associated this with the beverages' annual inflation rate instead of the SSB tax:

'Well, I didn't know specifically about sugar, because in my opinion everything costs more than before.' / 'Pues no sabía específicamente sobre el azúcar, porque según yo ahora todo cuesta más de lo que constaba antes.' (P20/M/18)

'Yes, I knew [about the tax], because I always used to go to buy the sodas and juices when I was younger ... And there was a time when all the prices went up. We bought it anyway, we did not stop buying them but I noticed the change in the price of the products ... But no, the truth is I did not know why it had been [the price increase].' / 'Si sabía [sobre impuesto], porque a mí siempre me tocaba ir a comprar la sodas y los jugos cuando estaba más pequeño ... Y hubo un tiempo que se fue para arriba todos los precios. Igual los comprábamos, no los dejamos de comprar pero si me di cuenta del cambio de precio de los productos ... Pero no, la verdad no sabía que por que había sido.' (P6/M/17)

\section{Perceptions of how the tax has affected sugar-sweetened beverage intake}

Participants mostly perceived that the SSB tax would not affect their SSB consumption patterns, because their intake had not changed:

'I don't think it will work, habits are hard to change.' / 'No creo que funcione, son hábitos difíciles de dejar pues.' (P9/M/17)

and that the tax would not affect them:

'It is a nonsense that they wanted to reduce the intake by doing that $[\operatorname{tax}]$... to me it doesn't sound possible to do; one peso per litre is not going to make me buy less.' / 'Se me hace una tontería que hayan querido reducir el consumo haciendo eso ... pero no me suena a mi algo posible que puedan hacer, o sea un peso el litro no va hacer que deje de comprar.' (P16/F/16)

Participants largely perceived that the tax would not influence their decision to buy SSB:

'No [tax won't affect], I would still buy them ... if I have the money I will buy them.' / 'No [va afectar el impuesto], si las compraría ... si tengo el dinero si las compro.' (P11/F/19)

or modify their, or their families', SSB intake:

'I don't think so [reduce intake], because while you keep liking it [SSB] you are going to keep buying it no matter the price ... it won't affect my family either.' / 'Yo pienso que no [reducir consumo], porque mientras te siga gustando pues vas a seguir comprando cueste lo que cueste ... a mi familia tampoco le va afectar.' (P25/F/17)

Some participants perceived that the taxation would not reduce SSB intake for other people, who would keep drinking the same beverages habitually:

'... If people are used to drinking soda with every meal, they are not going to say: "I'm going to stop drinking the beverage that I have been drinking all my life and the one my family have drunk just because they increased [the price] by 1 peso".' / '... si la gente ya está acostumbrada a tomar soda en cada comida que comen no es como que van a decir: "pues voy a dejar de consumir la bebida que he consumido toda mi vida y que mi familia ha consumido porque le subieron un peso".' (P10/F/18) 
However, other participants expressed that, although the SSB tax would not affect them personally, other people could be affected, particularly those from low socioeconomic backgrounds:

'Probably it [tax] could affect low-income people. Especially because $10 \%$ could sound like a lot, even though it is only 1 peso or probably 50 cents.' / 'Probablemente en personas de escasos recursos si podría afectar. Sobre todo porque ese $10 \%$ se puede escuchar muy fuerte a pesar de que solamente sea un peso o probablemente 50 centavos.' (P24/M/17)

'... Oh well, low-income people who like soda a lot. For example, I think if they raise the price they [lowincome people] will stop buying it. Because it would be a luxury, so I don't think it will be: "I don't have money and I'm going to buy that", no. I think they would drink more water or something cheaper.' / '...o pues a gente de bajos recursos que les gusta mucho la soda. Por ejemplo, yo creo que si le suben el precio si dejan de comprarla. Porque sería ya darse un lujo, así de que no tengo dinero y me voy a comprar eso pues no. Yo creo que tomarían más agua natural o algo más barato pues.' (P28/F/17)

\section{Reasons why the sugar-sweetened beverage tax was not perceived as having affected sugar-sweetened beverage intake}

Three sub-themes emerged when participants were asked to reflect on whether the tax would affect their SSB intake or not, and their reasons for this. Perceiving that the implemented increase in price was low and insufficient to change SSB intake, taste preferences and addiction to SSB were the main reported reasons why participants perceived the tax would not affect SSB intake at a personal level and for other people in Mexico.

\section{Price}

Participants largely perceived that the $10 \%$ price increase following implementation of the tax was too small:

'Because it is only $10 \%$, I do not take much into account.' / 'Pues porque solo son $10 \%$, o sea no lo tomo mucho en cuenta.' (P1/M/16)

and would not influence their SSB purchases:

'Well I say that it [price] didn't go up so much and I'm still going to buy it. It doesn't affect me because it doesn't go up so much, it rises like a peso or 50 cents ...' / 'Pues digo no subió tanto, pues si voy a comprarla. No me afecta que hay subido pues, porque no sube tanto sube como un peso o 50 centavos ...' (P14/F/15)
According to several participants, the tax would only affect them if it were higher:

'If the price was much higher than it was before, I think yes, I would consider it, but the $10 \%$ increase is not that much.' / 'Ya si el precio fuera mucho más alto, de cómo se compraba antes pues sı yo creo que si lo consideraría pero no con el $10 \%$ yo creo que no. por qué no es tan alto.' (P12/F/18)

'Probably if a soda can, I don't know, I think if it costs 10 or 20 pesos more, I would be like: "I better not, I'll better buy something else". / 'Probablemente si a una soda de lata, que no sé, yo creo que si cuesta 10 o cuesta 20 más serra un de que "no mejor me compro otra cosa".' (P13/M/19)

Participants who thought the tax should be higher, for it to affect SSB purchases, suggested that an average increase of 5-10 pesos per litre might cause them to reconsider:

'If it costs 10 pesos it needs to go up 5 more. Then it would be like: "Already went up too much, I'm not going to buy it anymore".' / 'Si cuesta 10 pesos que suba 5 más, ya sería como: "ya subió demasiado ya no voy a comprar".' (P28/F/17)

Some participants, however, perceived that an even higher price increase (between 15-20 and 40 pesos per litre) was necessary for them to consider changing:

'... they will have to increase 20 pesos per litre, in that way it is going to hurt.' / '... pero le tendrían que subir 20 pesos el litro, así si va a doler.' (P21/M/18)

'We need a bigger blow ... 15 to 25 pesos per litre, something like that.' / 'Para eso se necesitaría un golpe bastante grande ... 15 to 25 pesos por litro por ahí.' (P22/M/17)

A lack of awareness of the price of beverages was reported as a reason for dismissing taxation, as one participant explained:

'It won't affect me [tax] because, like me, other people don't remember the juice prices of last year.' / 'No me va afectar [impuesto] porque, mucha gente como yo no sabe o ni siquiera se acuerda cuanto costaba el jugo el año pasado.' (P10/F/18)

\section{Taste preferences}

It seemed that taste was an important driver of participants' SSB purchases, and some stated that when they liked the taste of a beverage, price was not an issue:

'The truth is that I do not buy it for the price, I buy it for the taste.' / 'La verdad no lo compro por precio lo compro por sabor.' (P3/M/16)

'... because as long as I continue to like it [SSB], I will continue buying at all costs.' / '... porque mientras te 
siga gustando pues voy a seguir comprando cueste lo que cueste.' (P25/F/17)

One participant further explained that sometimes he was willing to pay five times the retail price because of the taste and because consuming SSB is part of the enjoyment of certain activities:

'... I recently went to a concert and the soda of $700 \mathrm{ml}$ cost 60 pesos but I bought it, because it is soda and it is delicious, and I'm going to drink soda and it is refreshing.' / '... hace poco fui a un concierto y me costaba 60 pesos la soda de $700 \mathrm{ml}$ y la compre, porque es soda que rica, y voy a tomar soda y me voy a refrescar.' (P6/M/17)

\section{'Addiction' to sugar-sweetened beverages}

A few participants stated that the tax would not affect their SSB intake because of their perceived 'addiction' to SSB:

'Because it's an addiction [laughter], I will buy it anyway.' / 'Porque es el vicio [risa], si la compro de todas maneras.' (P14/F/15)

The term 'addiction' was also used when some participants talked about why they thought the tax would not work for people in Mexico:

'It's that it's like an addiction, it's like drugs, no matter the price they [people] are going to buy [SSB] because it is something that people consume and like.' / 'Es que es como un vicio, es como las drogas, no importa el precio las van a comprar [bebidas azucaradas] porque es algo que se consume y que les gusta.' (P19/M/18)

'Because most people are already addicted to a particular beverage. Because even if the government increases the price, it is likely that they [people] will keep drinking.' / 'Porque la mayoría de la gente ya está enviciada con alguna bebida. Porque aunque suban de precio lo más probable es que la sigan tomando.' (P4/F/17)

\section{Preferences for substitution of the taxed sugar- sweetened beverages}

Some participants reflected on what would happen to their SSB intake if prices increased more drastically. They mostly stated that if SSB prices increased further via a higher tax, they would consider substituting SSB with other beverages, such as home-made drinks (e.g. 100\% fruit juices and aguas frescas), non-caloric instantflavoured drinks and water:

'In that case, I would buy a juice, or you know what I would go to the fruit shop and I would buy 2 mangos and I would prepare a mango water, it's cheaper.' / 'Pues ahí si mejor me compro un jugo. O mejor me voy a la frutería me compro dos mangos y me hago el agua de mango me sale más barato.' (P17/F/15)

'I think it will be like in the old times when people prepared more flavoured waters at their homes. Buying [SSB] would be more like a luxury and it will be only for parties.' / 'Se hace que sería como antes que hacían más sus aguas naturales en sus casas. Y lo iba a ver más como un lujo nomas en fiestas o cosa así pero más que nada sería hacer bebidas caseras.' (P8/M/19)

\section{Discussion}

The present qualitative study of adolescents residing in north-west Mexico, a region with a high intake of SSB, demonstrated that participants were largely unaware of the SSB taxation. Overall, participants believed that the tax would not affect their SSB intake, apart from among people with a low income. The perceived insufficiency of the current price increase, taste preferences and perceived addiction to SSB appeared to be the most important reasons why participants felt taxation would not lead to SSB reductions. If SSB prices were to increase further via a higher tax, substitution of SSB would be towards home-made drinks, $100 \%$ fruit juices, non-caloric instantflavoured drinks and water.

Taxation of SSB in Mexico has been covered extensively by the national and international media ${ }^{(6)}$. The majority of adolescents in the present sample, however, appeared to be unaware of the tax. This may indicate that information on the SSB tax has not specifically been targeted at adolescents. Research on behavioural economics suggests that the way taxes are framed or presented could affect their impact $^{(13)}$. Thus, it may be that the current Mexican SSB tax has been framed in a way that makes it less salient to adolescents (e.g. size of the tax or the label attached to the tax) and, consequently, adolescents were mostly unaware or unaffected by it. Therefore, the development of a taxframing strategy directed at adolescents could enhance the impact of the SSB tax on the younger populations in Mexico.

An underlying assumption about tax policies is that individuals are aware that the change in prices is due to taxes, so they are conscious of the tax as a penalty for consumption behaviour ${ }^{(13,28)}$. However, our findings suggest that most adolescents in our sample were not aware of the price increases being due to tax. Although purchasing behaviours, financial independence and the amount of financial resources participants had (and how much they spent on food) were not explored in the present study, earlier literature has suggested that children normally have pocket money or an allowance, which they tend to spend on food and beverages ${ }^{(29-32)}$. Therefore, we could assume that adolescents in our sample were exposed to beverage prices, and thus SSB price increases; 
however, rationalisation, or the lack of it, may have played an important role in their decision making, leading to insensitivity to price changes ${ }^{(33)}$. Thus, more research is needed to investigate whether the reported tax unawareness might stem from lack of price exposure, rationalisation during food purchasing or insensitivity to price changes for other reasons, in a representative sample of adolescents in Mexico.

Adolescents in this sample largely perceived that the SSB tax would not cause them to reduce their SSB intake. The literature suggests that perceived effectiveness is the strongest predictor of acceptability ${ }^{(34)}$. Thus, the low levels of acceptance of the SSB taxation could cause increased resistance to perform the desired behaviour (i.e. reduce SSB intake) among consumers. Therefore, a future tax-framing strategy should also identify ways of promoting SSB tax acceptance among this sample of adolescents that would elicit rationalisation, helping them to approve the tax and reduce SSB intake ${ }^{(35)}$. On the other hand, knowledge and understanding of factors that influence consumers' acceptance are crucial to enhancing the objective of taxation ${ }^{(35)}$. Our findings highlighted three factors that could affect the impact of taxation among this sample of Mexican adolescents.

First, participants largely thought that a $10 \%$ increase would not be sufficient for them to reduce their SSB intake. Most studies that have simulated the effect of the SSB tax suggest that a $20 \%$ increase in SSB prices would reduce energy intake and the prevalence of obesity and being overweight in different countries ${ }^{(8-11,36)}$. Therefore, the current tax rate (approximately 10\%) could indeed be a drawback when aiming to reduce intake among adolescents from the middle and upper classes and among high consumers ${ }^{(37)}$. Second, adolescents referred to taste preferences as a factor hindering the potential effects of taxation. This finding stresses the importance of taste preferences in the context of SSB and is in agreement with earlier studies suggesting that taste is a factor influencing adolescents' decisions to consume $\mathrm{SSB}^{(38-40)}$. Third, some participants used the term 'addiction' as another factor that could affect the taxation's impact. This finding is consistent with results from a qualitative study exploring US adolescents' views on SSB taxation, where 'addiction' was also used by participants as a factor that could minimise the effect of the $\operatorname{tax}^{(41)}$. Participants in our sample explicitly used the term 'addiction' to explain why they did not change their SSB intake following the price increases, referring to SSB as a habit, but without indicating that they would observe physiological or emotional discomfort at the idea of not drinking SSB. Addiction has been described as 'an extreme form of habit formation',(12), and it is likely that adolescents have gone through a process of habit formation causing a dramatic increase in their SSB intake due to repetition of the behaviour and in response to environmental cues, such as home and school availability of $\mathrm{SSB}^{(16,42)}$. All of these factors should be considered by policy makers investigating ways to increase the effectiveness of the SSB tax in Mexico. Despite not having been discussed with participants in this sample, factors such as heavy marketing and publicity regulations ${ }^{(43,44)}$, parental and peer modelling ${ }^{(40,45)}$, leisure activities ${ }^{(46)}$, the environment (i.e. proximity to shops, home availability) ${ }^{(47)}$ and scarcity of potable water in schools ${ }^{(48)}$ and public spaces ${ }^{(49)}$ might influence beverage choices among young people, and could therefore also influence adolescents' perceptions and acceptance of SSB taxation. Further research into these factors is needed to provide a better sense of the taxation's contribution to SSB intake in Mexican adolescents.

When referring to tax effectiveness, it is also important to consider individual differences in levels of SSB intake, as how the SSB tax would affect SSB intake could vary across low, moderate and high SSB consumers. SSB intake in this sample of adolescents was over 1 litre per day, which is above the national median intake $(890 \mathrm{ml} / \mathrm{d})^{(50)}$, thus constituting our sample as high consumers. A recent study of Australian household data suggested that elasticity estimates (changes in the demanded quantity of a product following price changes) were lower for high, compared with moderate, consumers of SSB, suggesting that high consumers are less likely to be affected by price changes $^{(7)}$. However, this does not imply that the tax would not affect high consumers, as this group consumes more SSB in absolute terms than moderate consumers. Thus, the tax would have a greater impact upon the absolute consumption of high SSB consumers, potentially translating into body-mass reductions. However, the potential impact of this chain of effects on well-being remains unexplored. Similar studies need to be conducted in Mexico to investigate the effect of the tax across populations with different SSB intakes (i.e. high $v$. low), where links between intake and habit strength should be considered as mediating factors of any elasticity changes.

The main strength of the present study is the provision of in-depth information on adolescents' perceptions of the Mexican SSB taxation, in a sample with a high SSB intake. Interviews were conducted two years after implementation of the tax, which permitted exploration of whether the tax had influenced SSB intakes among this sample. The sample had a similar number of females and males. However, it was relatively small, the response rate (9.5\%) was low and data were collected from a single city in north-west Mexico - factors that hinder the external validity of the study. Another limitation was that most participants came from a medium/high socio-economic background, preventing the generalisation of findings to low-income adolescents. Nevertheless, thematic data saturation was reached for this sample of adolescents, suggesting the potential applicability of the findings to Mexican adolescents of similar characteristics.

The current findings provide important insights into the views of this sample of Mexican adolescents regarding the 
SSB tax, by pointing out several possible limitations of the tax policy in Mexico, as well as several perceived reasons why the tax would not lead to reductions in SSB intake. These factors should be considered by policy makers during any future tax reforms to improve the effectiveness of the SSB tax. Our findings could also inform the development of interventions targeted at Mexican adolescents that would complement the current SSB taxation.

\section{Acknowledgements}

Acknowledgements: The authors would like to thank all adolescents who participated in the interviews. Financial support: This study was funded by a Mexican Council of Science and Technology (CONACyT) PhD studentship to A.G.O.-A. CONACyT had no role in the design, analysis or writing of this article. Conflict of interest: None. Authorship: A.G.O.-A. formulated the research question(s), designed the study, collected and analysed the data, and wrote the manuscript. A.P. and R.J. assisted in the study design and provided critical input and revision to the manuscript. All authors approved the final version of the manuscript. Etbics of buman subject participation: This study was conducted according to the guidelines laid down in the Declaration of Helsinki and all procedures involving human participants were approved by the University of Bristol, School for Policy Studies Ethics Committee (SPS REC 14-15.A16). Written informed consent was obtained from all participants.

\section{Supplementary material}

To view supplementary material for this article, please visit https://doi.org/10.1017/S1368980017002695

\section{References}

1. Gutiérrez JP, Rivera-Dommarco J, Shamah-Levy $\mathrm{T}$ et al. (2013) Encuesta Nacional de Salud y Nutrición 2012. Resultados Nacionales. Cuernavaca: Instituto Nacional de Salud Pública.

2. Malik VS, Pan A, Willett WC et al. (2013) Sugar-sweetened beverages and weight gain in children and adults: a systematic review and meta-analysis. Am J Clin Nutr $\mathbf{9 8}$, 1084-1102.

3. Barquera S, Hernández-Barrera L, Tolentino ML et al. (2008) Energy intake from beverages is increasing among Mexican adolescents and adults. J Nutr 138, 2454-2461.

4. Colchero MA, Salgado JC, Unar-Munguía M et al. (2015) Changes in prices after an excise tax to sweetened sugar beverages was implemented in Mexico: evidence from urban areas. PLoS One 10, e0144408.

5. Colchero MA, Rivera-Dommarco J, Popkin BM et al. (2017) In Mexico, evidence of sustained consumer response two years after implementing a sugar sweetened beverage tax. Health Aff (Millwood) 36, 564-571.

6. Colchero MA, Guerrero-López CM, Molina M et al. (2016) Beverages sales in Mexico before and after implementation of a sugar sweetened beverage tax. PLoS One 11, e0163463.
7. Etilé F \& Sharma A (2015) Do high consumers of sugarsweetened beverages respond differently to price changes? A finite mixture iv-tobit approach. Health Econ 24, 1147-1163.

8. Briggs ADM, Mytton OT, Kehlbacher A et al. (2013) Overall and income specific effect on prevalence of overweight and obesity of $20 \%$ sugar sweetened drink tax in UK: econometric and comparative risk assessment modelling study. BMJ 347, f6198.

9. Manyema M, Veerman LJ, Tugendhaft A et al. (2016) Modelling the potential impact of a sugar-sweetened beverage tax on stroke mortality, costs and healthadjusted life years in South Africa. BMC Public Health 16, 405 .

10. Basu S, Vellakkal S, Agrawal S et al. (2014) Averting obesity and type 2 diabetes in India through sugar-sweetened beverage taxation: an economic-epidemiologic modeling study. PLoS Med 11, e1001582.

11. Dharmasena S \& Capps O (2012) Intended and unintended consequences of a proposed national tax on sugarsweetened beverages to combat the US obesity problem. Health Econ 21, 669-694.

12. Zhen C, Wohlgenant MK, Karns S et al. (2010) Habit formation and demand for sugar-sweetened beverages. $\mathrm{Am}$ J Agric Econ 93, 175-193.

13. Leicester A, Levell P \& Rasul I (2012) Tax and Benefit Policy: Insights from Behavioural Economics. London: Institute for Fiscal Studies.

14. Mazarello Paes V, Hesketh K, O'Malley C et al. (2015) Determinants of sugar-sweetened beverage consumption in young children: a systematic review. Obes Rev 16, 903-913.

15. Ebbeling CB (2014) Sugar-sweetened beverages and body weight. Curr Opin Lipidol 25, 1-7.

16. Tak NI, te Velde SJ, Oenema A et al. (2011) The association between home environmental variables and soft drink consumption among adolescents. Exploration of mediation by individual cognitions and habit strength. Appetite $\mathbf{5 6}$, 503-510.

17. Park S, Pan L, Sherry B et al. (2014) Consumption of sugar sweetened beverages among us adults in 6 states: behavioral risk factor surveillance system. Prev Chronic Dis 11, E65.

18. Avery A, Bostock L \& McCullough F (2014) A systematic review investigating interventions that can help reduce consumption of sugar-sweetened beverages in children leading to changes in body fatness. J Hum Nutr Diet 28, Suppl. 1, 52-64.

19. Piernas C, Barquera S \& Popkin BM (2014) Current patterns of water and beverage consumption among Mexican children and adolescents aged 1-18 years: analysis of the Mexican national health and nutrition survey 2012. Public Health Nutr 17, 2166-2175.

20. Hennink MM, Kaiser BN \& Marconi VC (2017) Code saturation versus meaning saturation. Qual Health Res 27, 591-608.

21. van Nes F, Abma T, Jonsson $\mathrm{H}$ et al. (2010) Language differences in qualitative research: is meaning lost in translation? Eur J Ageing 7, 313-316.

22. Birbili M (2000) Translating from one language to another. Social Research Update issue 31. http://sru.soc.surrey.ac.uk/ SRU31.html (accessed December 2016).

23. Al-Amer R, Ramjan L, Glew P et al. (2015) Translation of interviews from a source language to a target language: examining issues in cross-cultural health care research. J Clin Nurs 24, 1151-1162.

24. Esposito $N$ (2001) From meaning to meaning: the influence of translation techniques on non-English focus group research. Qual Health Res 11, 568-579.

25. Lincoln YS, González y González EM \& Aroztegui Massera C (2016) 'Spanish is a loving tongue...': performing qualitative 
research across languages and cultures. Qual Inq 22, 531-540.

26. Smith J \& Firth J (2011) Qualitative data analysis: the framework approach. Nurse Res 18, 52-62.

27. Gale NK, Heath G, Cameron E et al. (2013) Using the framework method for the analysis of qualitative data in multi-disciplinary health research. BMC Med Res Methodol 13, 117.

28. Alm J \& Bourdeaux C (2014) Applying Behavioural Economics to the Public Sector. Tulane University Economics Working Paper Series no. 1405. New Orleans, LA: Tulane University, Department of Economics.

29. Cash SB, McAlister AR, Adamwicz WL et al. (2017) Young food consumers: how do children respond to point-ofpurchase interventions? Presented at 2017 Allied Social Sciences Association (ASSA) Annual Meeting, Chicago, IL, USA, 6-8 January 2017.

30. Cowburn G, Matthews A, Doherty A et al. (2016) Exploring the opportunities for food and drink purchasing and consumption by teenagers during their journeys between home and school: a feasibility study using a novel method. Public Health Nutr 19, 93-103.

31. Dennisuk LA, Coutinho AJ, Suratkar S et al. (2011) Food expenditures and food purchasing among lowincome, urban, African-American youth. Am J Prev Med 40, 625-628.

32. Borradaile KE, Sherman S, Vander Veur SS et al. (2009) Snacking in children: the role of urban corner stores. Pediatrics 124, 1293-1298.

33. Harbaugh WT, Krause K \& Vesterlund L (2001) Are adults better behaved than children? Age, experience, and the endowment effect. Econ Lett 70, 175-181.

34. Petrescu DC, Hollands GJ, Couturier D-L et al. (2016) Public acceptability in the UK and USA of nudging to reduce obesity: the example of reducing sugar-sweetened beverages consumption. PLoS One 11, e0155995.

35. Bos C, der Lans IA, Van Rijnsoever et al. (2013) Understanding consumer acceptance of intervention strategies for healthy food choices: a qualitative study. BMC Public Health 13, 1073.

36. Schwendicke F \& Stolpe M (2017) Taxing sugar-sweetened beverages: impact on overweight and obesity in Germany. BMC Public Health 17, 88.

37. Cahuana-Hurtado L, Sosa-Rubi S, Rubalcava-Penafiel L et al.2013) Will the poor and high consumers benefit more by obesity prevention fiscal policies? Evidence from Mexico. https://mpra.ub.uni-muenchen.de/61277/1/MPRA_ paper_61277.pdf (accessed March 2017).
38. Battram DS, Piche L, Beynon C et al. (2016) Sugarsweetened beverages: children's perceptions, factors of influence, and suggestions for reducing intake. J Nutr Educ Behav 48, 27-34.e1.

39. Block JP, Gillman MW, Linakis SK et al. (2013) 'If it tastes good, I'm drinking it': qualitative study of beverage consumption among college students. I Adolesc Health 52, 702-706.

40. Bere E, Glomnes ES, te Velde SJ et al. (2008) Determinants of adolescents' soft drink consumption. Public Health Nutr 11, 49-56.

41. Krukowski CN, Conley KM, Sterling M et al. (2016) Peer reviewed: a qualitative study of adolescent views of sugarsweetened beverage taxes, Michigan, 2014. Prev Chronic Dis 13, E60.

42. Lally P, van Jaarsveld CHM, Potts HWW et al. (2010) How are habits formed: modelling habit formation in the real world. Eur J Soc Psychol 40, 998-1009.

43. Hernández Chávez P, Velasco-Bernal A, Aguilar-Menéndez P et al. (2017) Social media marketing on popular sugarsweetened beverages Facebook and Twitter pages in Mexico. FASEB J 31, 640.38.

44. Velasco A, Hernández IP \& Aguilar P (2016) Marketing strategies of the industry of sugar-sweetened beverages; monitoring of in-store special offers. FASEB J 30, Suppl. 1, 681.3.

45. Bogart LM, Elliott MN, Ober AJ et al. (2017) Home sweet home: parent and home environmental factors in adolescent consumption of sugar-sweetened beverages. Acad Pediatr 17, 529-536.

46. Mazzonetto AC \& Fiates GMR (2014) Perceptions and choices of Brazilian children as consumers of food products. Appetite 78, 179-184.

47. Van der Veur SS, Sherman SB, Lent MR et al. (2013) Corner store and commuting patterns of low-income, urban elementary school students. Curr Urban Stud 1, 166-170.

48. Carriedo A, Arenas AB, López N et al. (2013) Uso del mercadeo social para aumentar el consumo de agua en escolares de la ciudad de México. Salud Publica Mex 55, Suppl. 3, 388-396.

49. Ortega-Castaneda A (2016) Los factores determinantes del aumento del consumo de agua embotellada en México. Análisis desde el enfoque de políticas públicas. Master Thesis, Centro de Investigación y Docencia Económicas.

50. Jimenez-Aguilar A, Flores M \& Shamah-Levy T (2009) Sugarsweetened beverages consumption and BMI in Mexican adolescents: Mexican National Health and Nutrition Survey 2006. Salud Publica Mex 51, Suppl. 4, S604-S612. 